\section{3. 手術環境の清潔状藯の推移}

愛媛大 中央手術部

門田 稔熊本良悟 武智 誠 中野静子 永井勲柳原尚明

当手術部は開院以来 8 年間部内環境の清浄度を知る ために都内各所の空中浮遊塺埃数・空中浮遊細菌数 床壁表面付着細菌数を調査してきたが，今回行ったこ れらの 8 年目の調査結果を報告するとともに，これま での推移から現在行っている清净化対策について検討 を加えた.

8 年目の調查は前年までと同様に週一回の $0.2 \%$ ク ロルヘキシジングルコネート液噴霧 1 週間後に部内の 手術室・通路, リカバリー・I CUで行った. 空中浮 遊塺埃数は光散乱式粒子計数器 (リオン, $\mathrm{K} \mathrm{C}-0$ 1) を用い, $0.5 \mu$ 以上の塺埃数を空気 $1 \mathrm{cf}$ 当たりで示した. 空中浮遊細菌数はスリットサンプラー (M/G，200J) を用い，空気 $1 \mathrm{cf}$ 当たりのコロニ一数で示した. 休壁 表面付着細菌数は中和剤入りスタンプアガー（栄研, スタンプメディア B H I ）を使用し，床壁表面 $10 \mathrm{~cm}^{2}$ 当たりのコロニー数で表した。

今回行った 8 年目の調查結果, 手術室や通路を含め た清潔区域内においては前年に比べて特に細菌污染が 進んでいるところは認められなかった．準清潔区域の 通路床やの I C Uの床壁では污染の増大がみられた。

8 年間の推移をみると, 浮遊塵埃数は前半 4 年間に 比べ後半 4 年間の方が少なく, 変動も小さくなってい た. 浮遊細菌数も同様な傾向を示していたが，通路の み若干堌加の兆しがみられた. 朱壁付着細菌数は手術 室においてある特定の年以外安定した清浄度を保ち， 通路は 8 年目に準清潔区域で污染の增加傾向が認めら れた以外は顕著な変動はなかった。

以上の調查結果と 8 年間の推移から, 清潔区域内各 所の清浄度は現在行っている消毒方法で充分保持でき ることがわかった．ただ準清潔区域道路や I CUにお いては污染が増加し始め, 清潔区域内への污染侵入の 危険が考えられるのでその防止対策を検討する必要が ある。

\section{4. 新築手術室における清潔状龍の検討}

$\begin{array}{cl}\text { 北海道大 手術部 } & \\ \text { 三 浦 哲夫 } & \text { 秦 } \quad \text { 温 信 } \\ \text { 佐久間まこと } & \text { 倉上 親 治 } \\ \text { 木 村 智 政 } & \end{array}$

[目的〕昨年 6 月バイオクリーンルーム 1 室を含 む12室の清潔ホール型手術室を新築した。われわれは， その後の手術室における清潔状態について検索してき たが，今回はこの調查結果を検討し，手術室における 清潔維持について知見をえたので報告する.

〔方法】 バイオクリーンルームを除いた全手術室 にもHE PAフィルタを用い，垂直層流方式，換気回 数 40 回/ $\mathrm{h}$ を空調条件としている. 調査場所としてバ イオクリーンルームを除く 3 つの手術室を無作為に選 択した. 手術室使用開始に当って $20 \%$ グルタールアル デヒド噴霧による全域の殺菌消毒を行ったが，使用開 始前, 開始後 1 力月, 6 力月の清潔状態を調査した. 空中浮遊細菌については, スリットサンプラーを使用 して細菌数とともに細菌の同定をサブロー寒天培地 （ $\mathrm{S}$ 培地）およびトリプトソイ寒天培地 ( $\mathrm{T}$ 培地) を 用いて行った。床付着細菌については，スタンプアガ 一(栄研 1 号, 2 号) を用いて行った。また, 塵埃数 はパーティクルカウンターを用いて，0.5 0 以上の粒 子を測定した.

〔成績】 手術室使用開始前では空中細菌数は $\mathrm{S}$ 培 地 $0.06 \pm 0.09 / \mathrm{ft}^{3}$, T培地 $0.06 \pm 0.09 / \mathrm{ft}^{3}$, 床付着細 菌は 0 であった. 1 力月後では空中細菌数は $\mathrm{S}$ 培地 $0.70 \pm 0.50 / \mathrm{ft}^{3}, T$ 培地 $1.00 \pm 0.20 / \mathrm{ft}^{3}$, 床付着細菌 は 1 号 $22.3 \pm 14.5 / 10 \mathrm{~cm}^{2}, 2$ 号 $0.3 \pm 0.5 / 10 \mathrm{~cm}^{2}$ であ った. 6 力月後でも空中細菌は $\mathrm{S}$ 培地 $0.81 \pm 0.57 / \mathrm{ft}^{3}$, T培地 0 , 床付着細菌は 1 号 $0.30 \pm 0.50 / 10 \mathrm{~cm}^{2}, 2$ 号 0 と低值であった。䵇埃数は患者入室前は $877.6 \pm$ $515.5 / \mathrm{ft}^{3}$ であったが，手術中 $2,000 / \mathrm{ft}^{3}$ を越えること はなく, 最低 $215 / \mathrm{ft}^{3}$ であった。

[結論】 新築手術室においては比較的良好な清潔 状態が維持されており，その管理システムはほぼ満足 すべきものと考えられた。 